\title{
THE USE OF NIOBIUM AS AN ANODE MATERIAL IN LIQUID FILLED ELECTROLYTIC CAPACITORS
}

\author{
N. F. JACKSON and J. C. HENDY \\ Allen Clark Research Centre, Caswell, Towcester, Northants, U.K.
}

(Received October 17, 1973; in final form January 21, 1974)

\begin{abstract}
Field crystallisation during the anodisation of niobium can be reduced to a minimum by employing a phosphoric acid electrolyte at low temperature. For certain other electrolyte systems, reduced crystalline growth rates are obtained by increasing the solute concentration or by adding either phosphate or ethylene glycol.

Porous anodes were prepared from niobium powders of nominal particle size $8 \mu \mathrm{m}$ or $10 \mu \mathrm{m}$ using sintering temperatures of $1400-1800^{\circ} \mathrm{C}$. The capacitance of these bodies was in the range $4,600-10,000 \mu \mathrm{F} \mathrm{Vgm}^{-1}$. after anodising at $20^{\circ} \mathrm{C}$. Shelf tests on experimental capacitors filled with a concentrated sulphuric acid electrolyte indicated a maximum working temperature of $85^{\circ} \mathrm{C}$. Although chemical compatibility between the dielectric oxide and the sulphuric acid was maintained up to $125^{\circ} \mathrm{C}$, thermal effects on the oxide at this temperature resulted in unacceptably large increases in capacitance and leakage current. Endurance tests at $85^{\circ} \mathrm{C}$ of capacitors rated at $35 \mathrm{~V} / 200 \mu \mathrm{F}$ or $63 \mathrm{~V} / 60 \mu \mathrm{F}$ showed good stability of capacitance and dissipation factor over a period of 3000 hours. Final leakage currents were in the region of $10^{-4} \mu \mathrm{A} \mu \mathrm{F}^{-1} \mathrm{~V}^{-1}$ at $85^{\circ} \mathrm{C}$ and crystalline growth was greatly restricted.
\end{abstract}

\section{INTRODUCTION}

Niobium is in the same group ( $\mathrm{Vb})$ of the periodic table as tantalum but has roughly half the atomic weight. Both elements have very nearly the same atomic and ionic radii and their compounds are similar in properties. However, niobium has half the density of tantalum and since the price per kilogram of the two metals is about the same it presents an attractive substitute for tantalum in many applications, including electrolytic capacitors. Some of the relevant physical and chemical properties are summarised in Table 1. Although niobium oxide has a higher dielectric constant than tantalum oxide, a greater thickness of oxide per volt is formed when the former metal is anodised. In consequence, the capaci- tance values per unit area of oxide films on the two metals are similar for the same anodising voltage.

Niobium has two disadvantages with respect to tantalum in the context of capacitor applications. The first is the more marked tendency of anodic oxide films on niobium to undergo field crystallisa$\operatorname{tion}^{1,2,3}$. For example, calculations by the present authors suggest that the radial growth rate of crystalline areas may be up to 1000 times greater on niobium than on tantalum, under the same conditions of anodisation. However, as indicated in earlier work ${ }^{3}$, the growth rate during anodisation can be much reduced by employing low temperatures. The second disadvantage concerns the greater sensitivity of anodised niobium to heat treatment. On heating at temperatures in excess of $125^{\circ} \mathrm{C}\left(300^{\circ} \mathrm{C}\right.$ for tan-

TABLE I

Selected physical and chemical properties of niobium and tantalum

\begin{tabular}{|c|c|c|c|c|c|c|c|c|}
\hline Metal & $\begin{array}{l}\text { Atomic } \\
\text { weight }\end{array}$ & $\begin{array}{l}\text { Atomic } \\
\text { radius } \\
(\AA)\end{array}$ & $\begin{array}{l}\text { Density } \\
\left(\mathrm{gm} \mathrm{cm}^{-3}\right)\end{array}$ & $\begin{array}{l}\text { Melting } \\
\text { point } \\
\left({ }^{\circ} \mathrm{C}\right)\end{array}$ & $\begin{array}{l}\text { Free } \\
\text { energy of } \\
\text { formation } \\
\text { of oxide, } \\
\Delta \mathrm{G}^{\circ} \text {, at } \\
25^{\circ} \mathrm{C} \\
\left(\mathrm{kcal}^{-1}\right) \\
\left.\text { mole }^{-1}\right)\end{array}$ & $\begin{array}{l}\text { Standard } \\
\text { electrode } \\
\text { potential } \\
\text { for oxide } \\
\text { formation } \\
\mathrm{E}_{0} \text {, at } \\
25^{\circ} \mathrm{C} \\
\text { (volts) }\end{array}$ & $\begin{array}{l}\text { Oxide } \\
\text { dielectric } \\
\text { constant } \\
\text { at } 25^{\circ} \mathrm{C}\end{array}$ & $\begin{array}{l}\text { Oxide } \\
\text { thickness } \\
\text { at } 25^{\circ} \mathrm{C} \\
(\AA \text { volt } \\
(1)\end{array}$ \\
\hline $\mathrm{Nb}$ & 92.91 & 1.46 & 8.4 & 2468 & -432 & -0.65 & 41 & $\sim 25$ \\
\hline Тa & 180.95 & 1.46 & 16.6 & 2996 & -471 & -0.81 & 27 & 16 \\
\hline
\end{tabular}


talum) a semiconducting region is formed within the oxide $^{4}$. This leads to substantial increases in capacitance and dissipation factor and a marked dependence of both of these parameters on voltage and temperature. In addition, there is evidence to suggest that in the case of niobium oxide some mechanical damage may also occur. The combined effects are so deleterious that it seems very unlikely that niobium could ever be used for solid electrolytic capacitors, the preparation of which requires the thermal decomposition of manganese nitrate.

The present paper examines the possibility of using niobium for liquid filled capacitors. It was recognised that certain limitations in the voltage and temperature of operation would have to be imposed. However, it was considered that this would be acceptable provided that the high reliability normally associated with tantalum capacitors was retained.

\section{ANODISATION}

\subsection{Foil}

Initial anodisation studies were performed with a supply of $0.0025 \mathrm{~cm}$ thick niobium foil of capacitor grade. This material was degreased in warm methyl ethyl ketone prior to anodisation. The anodising was carried out by applying a constant current of $2 \mathrm{~mA}$ $\mathrm{cm}^{-2}$, until the voltage reached a predetermined level at which it was held constant. The indicated times of anodisation given in this paper refer to the period at constant voltage.

As shown in earlier work with tantalum ${ }^{3}$, it is possible to obtain a guide to the radial growth rate of crystalline oxide by measuring the time to reach the

TABLE II

Values of $t_{\min }$ for niobium specimens anodised at $50 \mathrm{~V}$ in electrolytes of $2 \%$ concentration at $85^{\circ} \mathrm{C}$ for 60 minutes

\begin{tabular}{lcll}
\hline $\begin{array}{l}\text { Electrolyte } \\
\text { composition } \\
\left(20 \mathrm{gl}^{-1}\right)\end{array}$ & $\begin{array}{l}\text { Electrolyte } \\
\text { pH at } 25^{\circ} \mathrm{C}\end{array}$ & $\begin{array}{l}\text { Electrolyte } \\
\text { conductivity } \\
\text { at } 25^{\circ} \mathrm{C} \\
\left(\Omega^{-1} \mathrm{~cm}^{-1}\right)\end{array}$ & $\begin{array}{l}\mathrm{t}_{\text {min }} \\
(\mathrm{min})\end{array}$ \\
\hline $\mathrm{HNO}_{3}$ & 0.6 & 0.13 & 4 \\
$\mathrm{H}_{2} \mathrm{SO}_{4}$ & 0.7 & 0.11 & 7 \\
$(\mathrm{COOH})_{2}$ & 1.3 & 0.031 & 6 \\
$\mathrm{H}_{3} \mathrm{PO}_{4}$ & 1.6 & 0.041 & not \\
& & & observed \\
$(\mathrm{COONa})_{2}$ & 8.2 & 0.015 & 6 \\
$\mathrm{Na}_{2} \mathrm{~B}_{4} \mathrm{O}_{7}$ & 9.3 & 0.006 & 7 \\
$\mathrm{Na}_{2} \mathrm{CO}_{3}$ & 11.1 & 0.031 & 6 \\
\hline
\end{tabular}

first minimum value in the current-time characteristic at constant voltage. This value, which has been called $t_{\mathrm{min}}$, increases as the growth rate decreases. Values of $t_{\min }$ for niobium anodised in a number of different electrolytes are given in Table II. Unlike the results of similar experiments with tantalum, there was no apparent relationship between radial growth rate and the $\mathrm{pH}$ of the electrolyte. Of the electrolytes studied only phosphoric acid showed any marked ability to minimise the growth of crystalline oxide. Relative

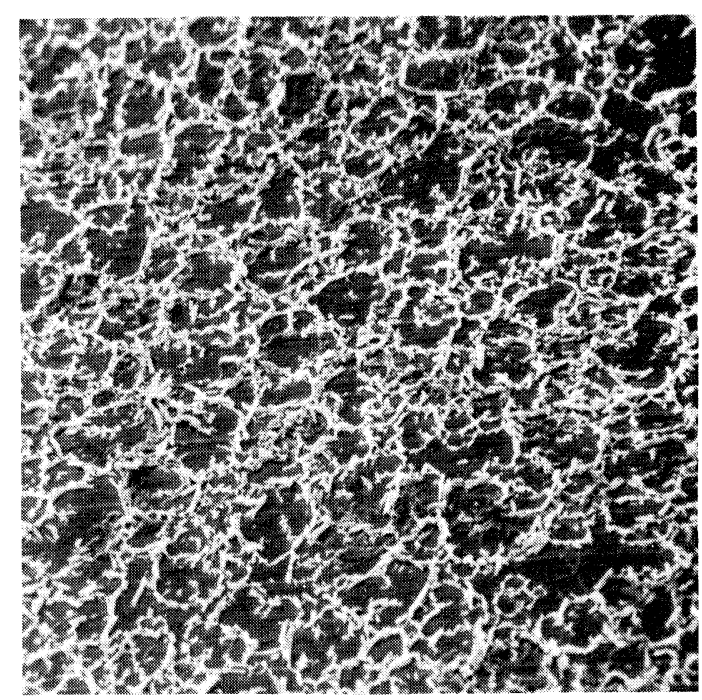

(a) $\times 200$

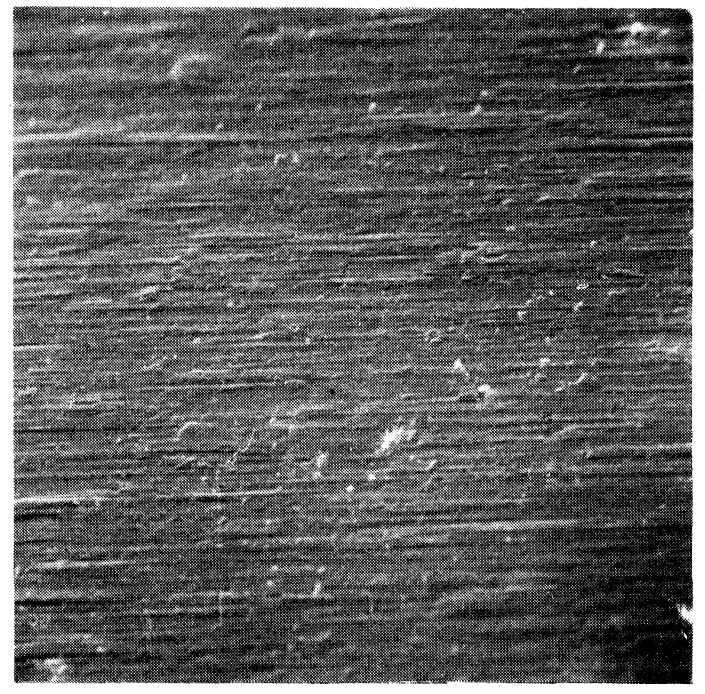

(b) $\times 200$

FIGURE 1 Degree of field crystallisation after anodising niobium foil at $50 \mathrm{~V}, 85^{\circ} \mathrm{C}, 60$ Minutes: (a) $2 \% \mathrm{H}_{2} \mathrm{SO}_{4}$, (b) $2 \% \mathrm{H}_{3} \mathrm{PO}_{4}$. 
degrees of crystallisation after polarisation in $2 \%$ sulphuric acid and $2 \%$ phosphoric acid are illustrated in Figure 1.

Increasing the concentration of the sulphuric acid electrolyte resulted in a substantial decrease in growth rate for concentrations of $20 \%$ or above (Table III).

\section{TABLE III}

Values of $t_{\min }$ for niobium specimens anodised at $50 \mathrm{~V}$ in sulphuric acid electrolytes at $85^{\circ} \mathrm{C}$ for $60 \mathrm{~min}$.

\begin{tabular}{ll}
\hline $\begin{array}{l}\text { Electrolyte } \\
\begin{array}{l}\text { Concentration } \\
(\% \mathrm{w} / \mathrm{v})\end{array}\end{array}$ & \multicolumn{1}{c}{$\begin{array}{l}\mathrm{t}_{\min } \\
(\mathrm{min})\end{array}$} \\
\hline 0.2 & 6 \\
2.0 & 7 \\
20 & 15 \\
40 & Not observed \\
& $(>60)$ \\
\hline
\end{tabular}

This result is important, since the more concentrated solutions have physical properties which render them ideal for use as working electrolytes in liquid filled capacitors. Qualitatively similar results were observed after anodising in oxalic acid electrolytes of varying concentration.

In the light of the above results, experiments were performed to find out if the growth rate in other electrolytes could be reduced by making small additions of phosphoric acid (Table IV).

It was found that the phosphoric acid additions had a considerably greater effect in sulphuric than in oxalic acid. In a further experiment niobium foil was anodised at 50V for 360 min either in $40 \%$ sulphuric acid or the same electrolyte containing $1 \%$ phosphoric acid, the temperature of both solutions being held at $85^{\circ} \mathrm{C}$. The inhibiting effect of the phosphoric acid is illustrated in Figure 2. Phosphoric acid

TABLE IV

Values of $t_{\min }$ for niobium specimens anodised at $50 \mathrm{~V}$ in various electrolytes at $85^{\circ} \mathrm{C}$ for $60 \mathrm{~min}$

\begin{tabular}{ll}
\hline $\begin{array}{l}\text { Electrolyte composition } \\
(\% \mathrm{w} / \mathrm{v})\end{array}$ & $\begin{array}{l}\mathrm{t}_{\min } \\
(\mathrm{min})\end{array}$ \\
\hline $2 \% \mathrm{H}_{2} \mathrm{SO}_{4}+0.1 \% \mathrm{H}_{3} \mathrm{PO}_{4}$ & 7 \\
$2 \% \mathrm{H}_{2} \mathrm{SO}_{4}+$ & not observed \\
$(>60)$ \\
$2 \%(\mathrm{COOH})_{2}$ & 6 \\
$2 \%(\mathrm{COOH})_{2}+0.1 \% \mathrm{H}_{3} \mathrm{PO}_{4}$ & 14 \\
\hline
\end{tabular}

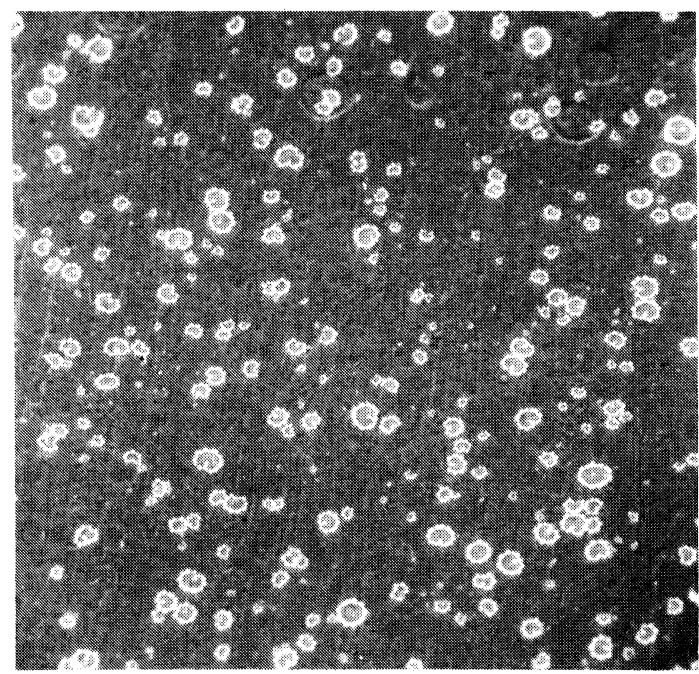

(a) $\times 200$

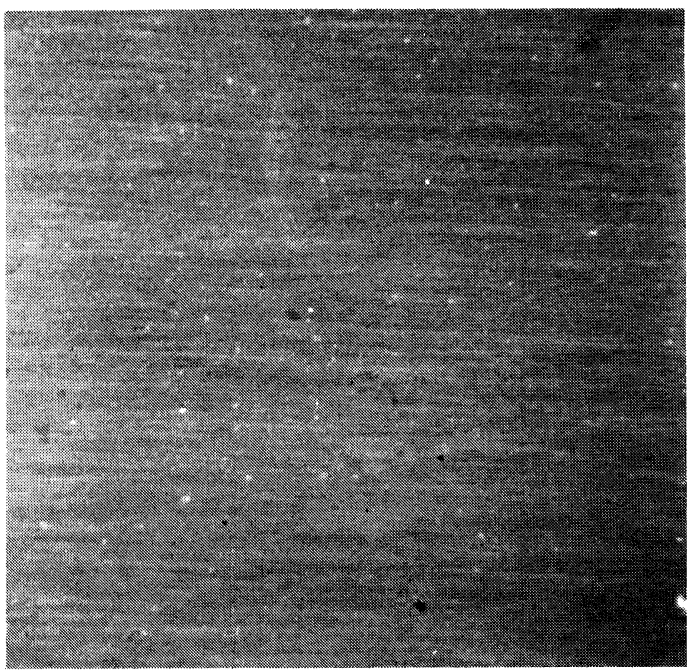

(b) $\times 200$

FIGURE 2 Degree of crystallisation after anodising niobium foil in $\mathrm{H}_{2} \mathrm{SO}_{4}$ electrolytes at $50 \mathrm{~V}, 85^{\circ} \mathrm{C}, 360$ minutes: (a) $40 \% \mathrm{H}_{2} \mathrm{SO}_{4}$, (b) $40 \% \mathrm{H}_{2} \mathrm{SO}_{4}+1 \% \mathrm{H}_{3} \mathrm{PO}_{4}$.

additions were also found to be effective in reducing crystalline growth during anodisation in nitric acid.

The effect on the crystalline growth rate of adding ethylene glycol to an oxalic acid electrolyte is shown in Table V. For a $50 \%$ addition, the crystalline oxide covered less than $1 \%$ of the surface by comparison with approximately $100 \%$ coverage for the aqueous solution. It was also established that combined additions of glycol and phosphate to the oxalic acid solution had an additive effect.

On the basis of these experiments, it was concluded that phosphoric acid was a suitable anodising 
TABLE V

\begin{tabular}{|c|c|}
\hline $\begin{array}{l}\text { Values of } t_{\mathrm{m}} \\
\text { specimens anodi } \\
\text { oxalic acid elect } \\
\text { additions of et } \\
85^{\circ} \mathrm{C} \text { fo }\end{array}$ & $\begin{array}{l}\text { for niobium } \\
\text { d at } 50 \mathrm{~V} \text { in } 2 \% \\
\text { lyte, containing } \\
\text { lene glycol, at } \\
60 \text { min }\end{array}$ \\
\hline $\begin{array}{l}\text { Ethylene glycol } \\
\text { addition } \\
\text { (vol. \%) }\end{array}$ & $\stackrel{\mathrm{min}}{\min })^{\mathrm{min}}$ \\
\hline 0 & 6 \\
\hline 1 & 6 \\
\hline 10 & 15 \\
\hline 25 & not observed \\
\hline 50 & $\xi_{(>60)}$ \\
\hline
\end{tabular}

medium for niobium. Where necessary, particularly if higher anodising voltages are required, additions of glycol are advantageous. For other electrolytes, improved anodisation can generally be achieved by increasing the concentration, adding either phosphoric acid or glycol, or a combination of these artifices. In general, these results are qualititatively similar to those observed with tantalum.

\subsection{Porous Anodes}

2.2.1 Experimental Two batches of capacitor grade niobium powder, designated $\mathrm{A}$ and $\mathrm{B}$, were obtained from different suppliers. Powder A was nominally graded as $8 \mu \mathrm{m}$ and powder B as $10 \mu \mathrm{m}$. However, there was a considerable spread in particle size, in the range $2 \mu \mathrm{m}-25 \mu \mathrm{m}$ for powder $\mathrm{A}$ and $2 \mu \mathrm{m}-50 \mu \mathrm{m}$ for powder B Figure 3). The powders were coated with an organic binder and pressed into a cylindrical shape, $0.706 \mathrm{~cm}$ diameter and $1.188 \mathrm{~cm}$ long. The pressed bodies, which incorporated tantalum riser wires, had a density of $5.0 \mathrm{gm} \mathrm{cm}^{-3}$. After dewaxing, the bodies were sintered in vacuo at temperatures of $1400^{\circ} \mathrm{C} 1600^{\circ} \mathrm{C}$ and $1800^{\circ} \mathrm{C}$. The interior and exterior structures of bodies sintered at $1800^{\circ} \mathrm{C}$ are shown in Figure 4 (powder A) and Figure 5(a) and (b) (powder B). The improved interior porosity of bodies prepared from powder $\mathrm{A}$, a factor resulting from the lower average particle size, is apparent. Both exterior surfaces showed reduced porosity in consequence of 'smearing' on withdrawal from the die after pressing. The influence of reduced sintering temperature, illustrated in Figure 5(c) and (d), for powder B treated at $1400^{\circ} \mathrm{C}$ was to increase porosity by reducing powder agglomeration. At the lower temperatures, the powder particles also showed less general smoothing and less rounding of the edges.

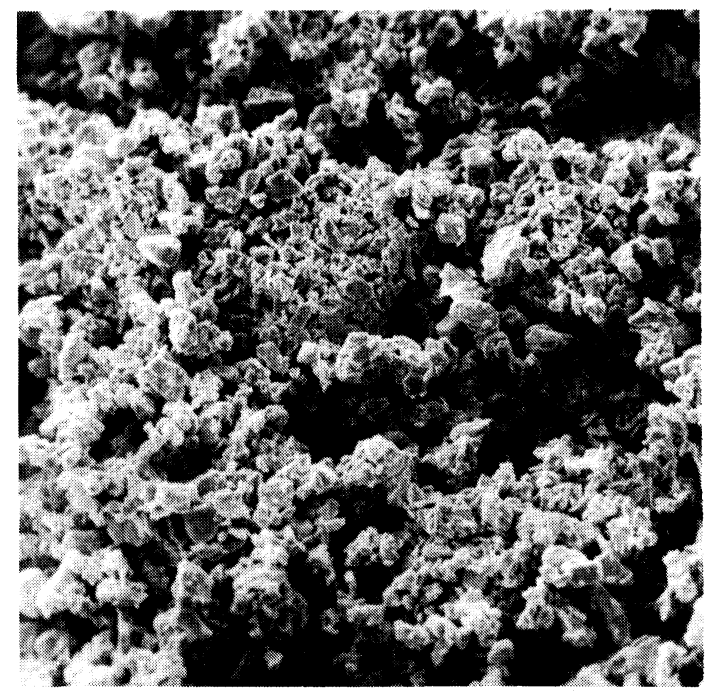

(a) $\times 200$

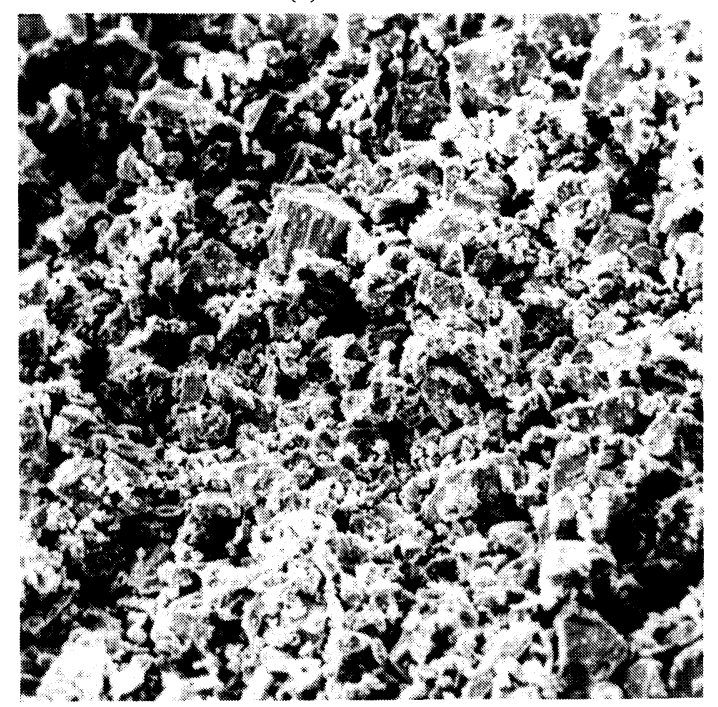

(b) $\times 200$

FIGURE 3 Niobium Powders: (a) powder A, (b) powder B.

Preliminary experiments quickly confirmed that low temperature anodisation would be essential if field crystallisation was to be minimised (Figure 6). In consequence, all the subsequent work was performed in $1 \%$ phosphoric acid at $20^{\circ} \mathrm{C}$. For anodising voltages up to $110 \mathrm{~V}$, a current density of $50 \mathrm{~mA}$ per anode $\left.(\sim 0.05 \mathrm{~mA} \mathrm{~cm})^{-2}\right)$ was applied to $75 \mathrm{~V}$ at which voltage the current was reduced to $20 \mathrm{~mA}$ per anode. For voltages above $110 \mathrm{~V}, 50 \mathrm{~mA}$ per anode was applied to a voltage $50 \mathrm{~V}$ below the forming voltage and the anodisation was then completed at 

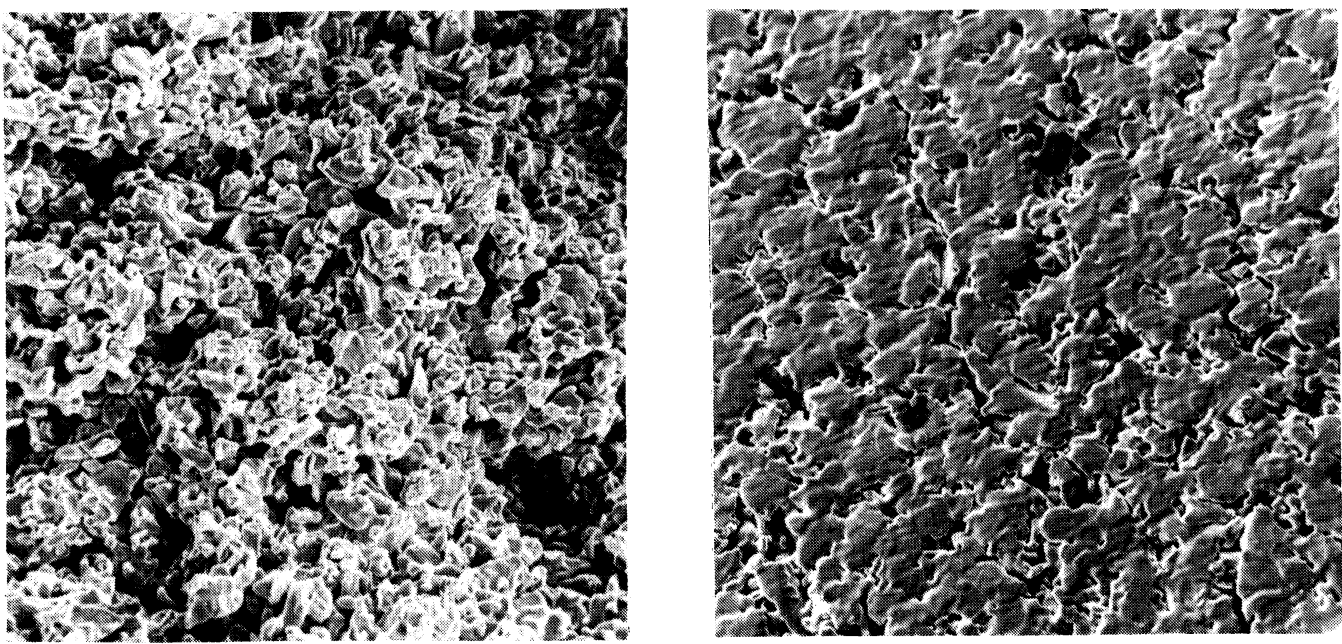

(b) $\times 200$

(a) $\times 200$

(1).

sintering temperature of $1800^{\circ} \mathrm{C}$ : (a) section, (b) surface.

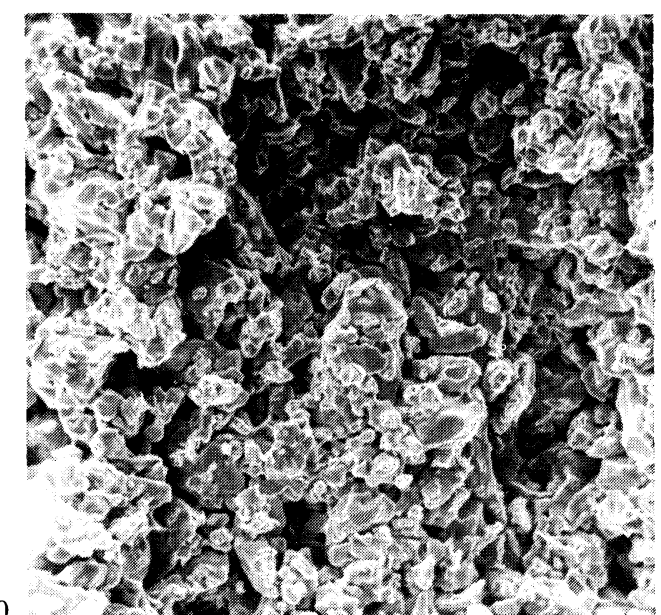

(a) $\times 200$

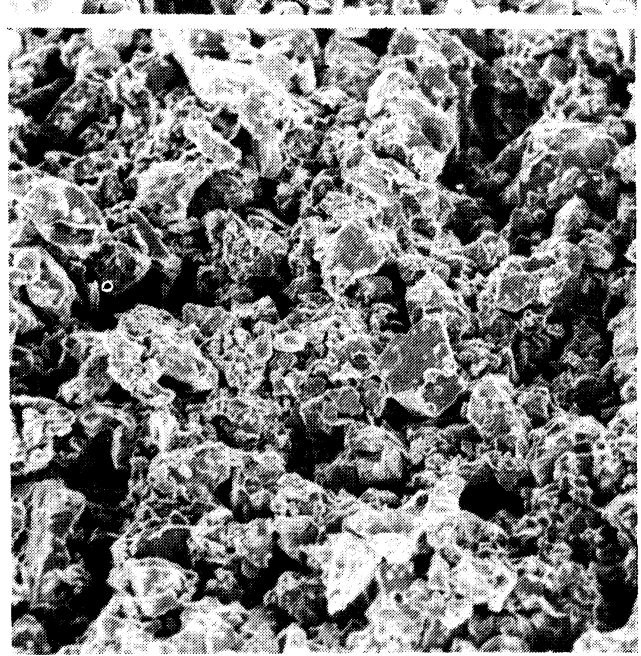

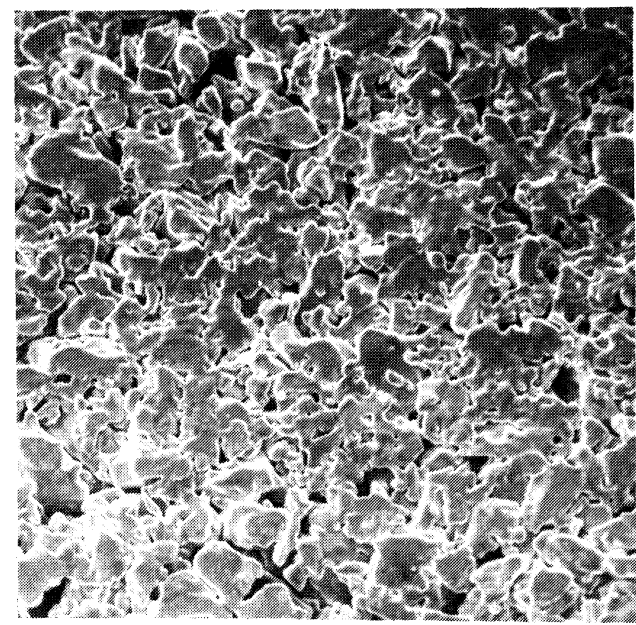

(b) $\times 200$

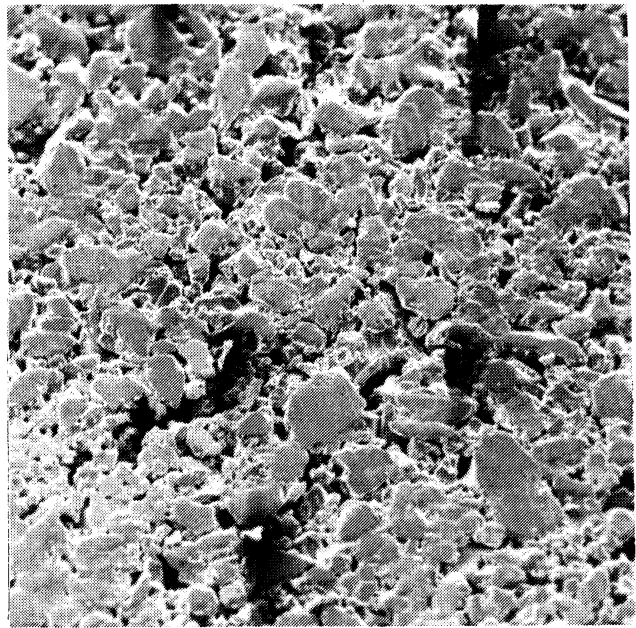

(d) $\times 200$

(c) $\times 200$

FIGURE 5 Porous anodes prepared from powder B: (a) + (b) section and surface $\left(1800^{\circ} \mathrm{C}\right.$ sintering temperature), (c) + (d) section and surface $\left(1400^{\circ} \mathrm{C}\right.$ sintering temperature $)$. 


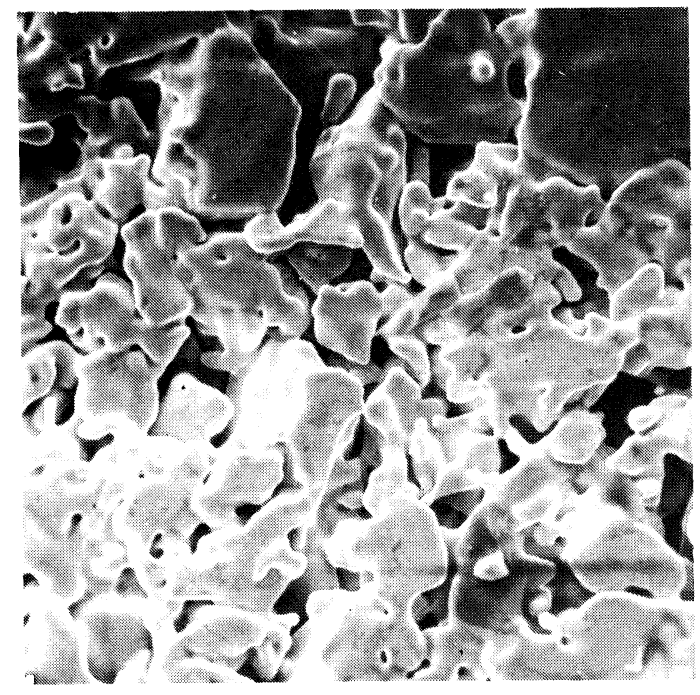

(a) $\times 500$

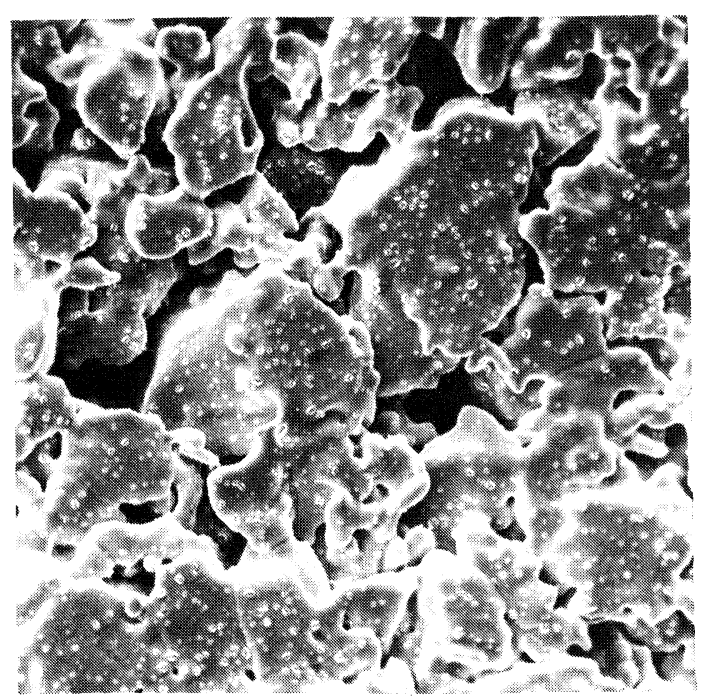

(b) $\times 500$

FIGURE 6 Degree of crystallisation after anodising niobium bodies prepared from powder $\mathrm{B}$ at $1800^{\circ} \mathrm{C}$ in $1 \%$ $\mathrm{H}_{3} \mathrm{PO}_{4}$ : (a) $110 \mathrm{~V}, 20^{\circ} \mathrm{C}$, (b) $80 \mathrm{~V}, 70^{\circ} \mathrm{C}$.

$20 \mathrm{~mA}$ per anode. All the specimens were held at the forming voltage for 60 minutes.

2.2.2 Results The influence of sintering temperature on capacitance and leakage current after anodising to $110 \mathrm{~V}$ is shown in Table VI. Both parameters were measured at half the formation voltage in $40 \%$ sulphuric acid at $20^{\circ} \mathrm{C}$. The leakage current was recorded after 30 minutes polarisation and the capacitance immediately afterwards with a $50 \mathrm{~Hz}$ ripple voltage superimposed. The anodes showed an increase in capacitance of less than $2 \%$ in raising the applied bias voltage from $5 \mathrm{~V}$ to $35 \mathrm{~V}$; in the same voltage range the dissipation factor decreased slightly.
As anticipated from the values of the particle size, powder A produced anodes with significantly greater surface areas than B. Reducing the sintering temperature from 1800 to $1400^{\circ} \mathrm{C}$ caused the surface areas to increase by $50-60 \%$. Not unexpectedly, this also resulted in higher leakage currents. The latter effect was much more marked for powder $\mathrm{B}$, which was capable of producing anodes at $1600^{\circ} \mathrm{C}$ and $1800^{\circ} \mathrm{C}$ sintering with leakage currents comparable to tantalum. However, at $1400^{\circ} \mathrm{C}$ sintering the difference in leakage current between anodes prepared from the two powders was much smaller.

The difference in purity between the anodes was reflected in the ability to increase the anodising voltage above $110 \mathrm{~V}$. Anodes from powder A prepared

TABLE VI

Capacitance and leakage current of niobium anodes formed at $110 \mathrm{~V}$

\begin{tabular}{lllcll}
\hline & $\begin{array}{l}\text { Sintering } \\
\text { temperature }\end{array}$ & \multicolumn{2}{c}{ Capacitance } & \multicolumn{2}{c}{ Leakage current } \\
Powder & $\left.{ }^{\circ} \mathrm{C}\right)$ & $(\mu \mathrm{F})$ & $\left.(\mu \mathrm{F} \mathrm{V} \mathrm{gm})^{-1}\right)^{+}$ & $(\mu \mathrm{A})$ & $\left(\mu \mathrm{A} \mathrm{F}^{-1} \mathrm{~V}^{-1} \times 10^{3}\right)^{++}$ \\
\hline $\mathrm{A}$ & 1400 & 197 & 10,000 & 45 & 4.2 \\
& 1600 & 160 & 8,400 & 30 & 3.4 \\
& 1800 & 130 & 6,700 & 23 & 3.2 \\
$\mathrm{~B}$ & 1400 & 150 & 7,600 & 17 & 2.1 \\
& 1600 & 125 & 6,400 & 0.50 & 0.07 \\
& 1800 & 90 & 4,600 & 0.15 & 0.03 \\
\hline
\end{tabular}

Note: + Calculated for the forming voltage ++ Calculated for the measuring voltage 


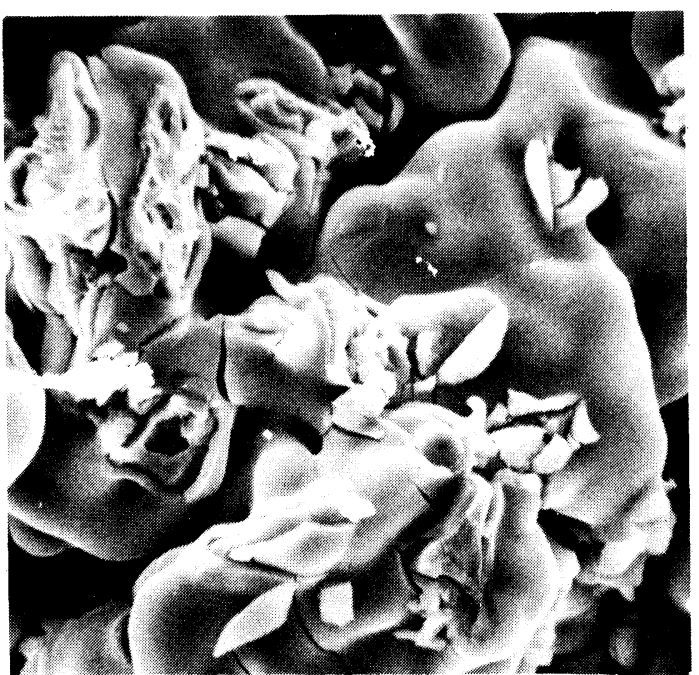

(a) $\times 2000$

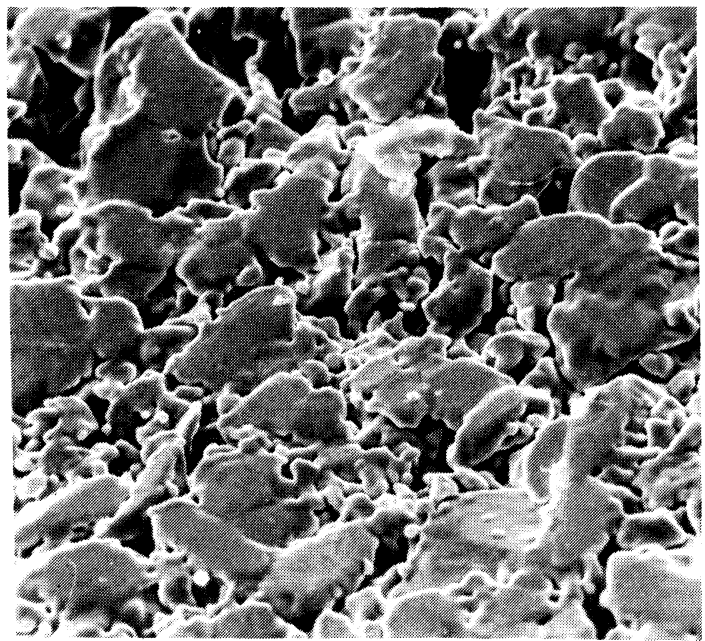

(c) $\times 500$

FIGURE 7 Niobium anodes formed in $1 \% \mathrm{H}_{3} \mathrm{PO}_{4}$ at $160 \mathrm{~V}$ or 200V: (a) powder A sintered $1600^{\circ} \mathrm{C}$, formed $160 \mathrm{~V}$, section, (b) as (a), surface, (c) powder B sintered $1600^{\circ} \mathrm{C}$,

at any of the three sintering temperatures could not be anodised appreciably above $125 \mathrm{~V}$ without inducing excessive field crystallisation and unacceptably high leakage currents. On the other hand anodes from powder B sintered at $1800^{\circ} \mathrm{C}$ could be anodised satisfactorily to $200 \mathrm{~V}$; however, when the sintering temperature was reduced to $1600^{\circ} \mathrm{C}$, field crystallisation became appreciable at $190 \mathrm{~V}$. Representative values of capacitance and leakage current for different sintering temperatures and anodising voltages are given in Table VII and a selection of micrographs of the anodised bodies is displayed in Figure 7.

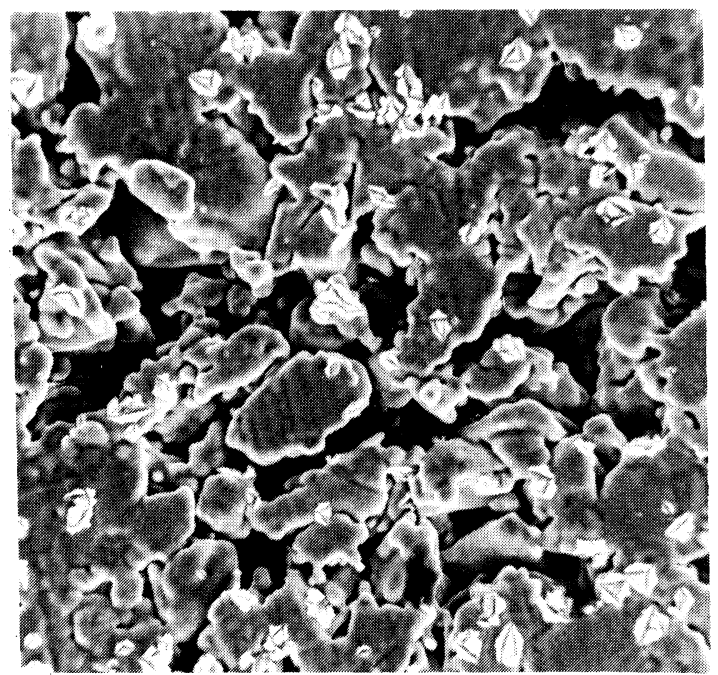

(b) $\times 500$

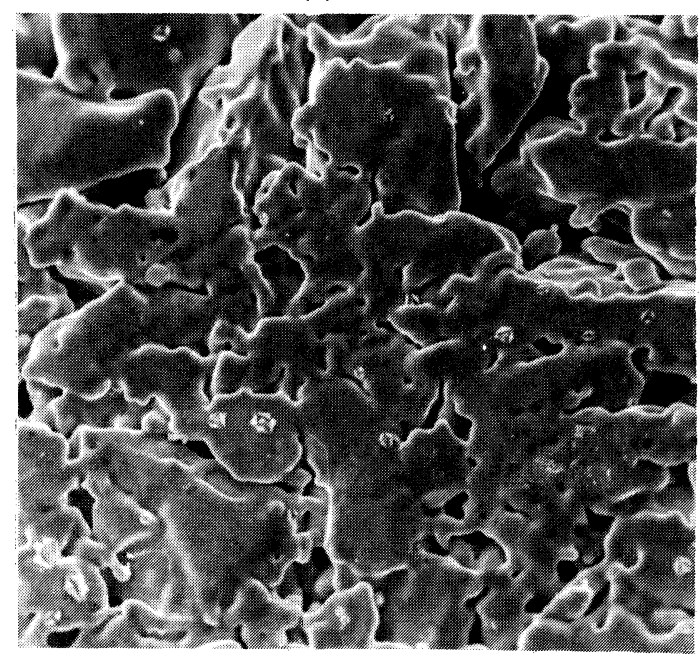

(d) $\times 500$

formed $160 \mathrm{~V}$, surface (d) powder $\mathrm{B}$, sintered $1800^{\circ} \mathrm{C}$, formed $200 \mathrm{~V}$, surface.

The measurements in Table VII were made using the same conditions as those described previously.

\section{CAPACITORS}

\subsection{Experimental}

The majority of the capacitors prepared for testing were of the standard tubular construction (T3 case size), employing platinised silver cans. A small number of the button construction (Plessey Castanet type A) having a sintered silver powder cathode were 
TABLE VII

Capacitance and leakage current of niobium anodes formed at different voltages

\begin{tabular}{lllll}
\hline & $\begin{array}{l}\text { Sintering } \\
\text { temperature } \\
\text { Powder }\end{array}$ & $\begin{array}{l}\text { Anodising } \\
\text { voltage } \\
\text { (volts) }\end{array}$ & $\begin{array}{l}\text { Capacitance } \\
(\mu \mathrm{F})\end{array}$ & $\begin{array}{l}\text { Leakage current } \\
\left(\mu \mathrm{A}^{-1} \mathrm{~F}^{-1} \times 10^{3}\right)\end{array}$ \\
\hline B & 1800 & 200 & 47 & 0.05 \\
$\mathrm{~A}$ & 1600 & 125 & 110 & 3.5 \\
& & 142 & 99 & 10 \\
B & 1600 & 160 & 80 & 55 \\
& & 160 & 90 & 0.07 \\
\hline
\end{tabular}

TABLE VIII

Nominal voltage and capacitance ratings of experimental niobium capacitors (series 1-4)

\begin{tabular}{llllll}
\hline & & $\begin{array}{l}\text { Sintering } \\
\text { temperature }\end{array}$ & $\begin{array}{l}\text { Anodising } \\
\text { voltage } \\
\text { Series }\end{array}$ & Powder & \multicolumn{2}{c}{ Capacitor Rating } \\
& $\left.{ }^{\circ} \mathrm{C}\right)$ & Working voltage & $\begin{array}{l}\text { Capacitance } \\
(\mu \mathrm{F})\end{array}$ \\
\hline 1 & A & 1400 & 100 & 35 & 200 \\
2 & A & 1800 & 100 & 35 & 135 \\
3 & B & 1800 & 100 & 35 & 100 \\
4 & B & 1800 & 180 & 63 & 60 \\
\hline
\end{tabular}

TABLE IX

Niobium capacitors subjected to shelf tests at $125^{\circ} \mathrm{C}$ for 100 hours

\begin{tabular}{|c|c|c|c|c|c|c|c|}
\hline \multirow[b]{2}{*}{ Series } & \multirow[b]{2}{*}{$\begin{array}{l}\text { Working } \\
\text { electrolyte }\end{array}$} & \multicolumn{2}{|c|}{$\begin{array}{c}\text { Initial values at } \\
20^{\circ} \mathrm{C}\end{array}$} & \multirow{2}{*}{$\begin{array}{l}\text { Final values } \\
\text { at } 20^{\circ} \mathrm{C} \\
\text { Capacitance } \\
(\mu \mathrm{F})\end{array}$} & \multirow[b]{2}{*}{$\begin{array}{l}\text { Leakage } \\
\text { current } \\
(\mu \mathrm{A})\end{array}$} & \multirow[b]{2}{*}{$\begin{array}{l}\text { Capacitance } \\
\text { change } \\
(\%)\end{array}$} & \multirow{2}{*}{$\begin{array}{l}\text { Final } \\
\text { leakage } \\
\text { current } \\
\left(\mu \mathrm{A} \mu \mathrm{F}^{-1}\right. \\
\left.\mathrm{V}^{-1} \times 10^{3}\right)\end{array}$} \\
\hline & & $\begin{array}{c}\text { Capacitance } \\
(\mu \mathrm{F})\end{array}$ & $\begin{array}{l}\text { Leakage } \\
\text { current } \\
(\mu \mathrm{A})\end{array}$ & & & & \\
\hline 2 & $\mathrm{H}_{2} \mathrm{SO}_{4}$ & 135 & 7.6 & 179 & 28.1 & 25 & 4.5 \\
\hline 3 & $\mathrm{H}_{2} \mathrm{SO}_{4}$ & 103 & 1.4 & 122 & 3.2 & 18 & 0.75 \\
\hline 3 & $\mathrm{LiCl}$ & 103 & 1.4 & 122 & 3.2 & 18 & 0.75 \\
\hline
\end{tabular}

also prepared. All the anodisations were performed in $1 \%$ phosphoric acid at $20^{\circ} \mathrm{C}$ using the forming conditions previously described. In general, the units were filled with $40 \% \mathrm{w} / \mathrm{w}$ sulphuric acid $(49 \% \mathrm{w} / \mathrm{v})$ except for a small number which contained 30\% lithium chloride.

Experimental capacitors rated at four different capacitance and voltage values, designated series 1-4, were examined. Details of the conditions of preparation are given in Table VIII together with nominal ratings for the tubular types only. Leakage currents of the capacitors were measured at the rated working voltage and capacitance and dissipation factor at the same voltage with $50 \mathrm{~Hz}$ ripple applied.

\subsection{Results}

In order to determine the upper temperature of operation, the capacitors were initially subjected to shelf tests. So as to be able to differentiate between chemical and thermal effects the units under test were filled either with sulphuric acid or lithium chloride. The results for a period of storage of 100 hours at $125^{\circ} \mathrm{C}$ are given in Table IX for capacitors from series 2 and 3. Both series showed substantial increases in capacitance and leakage current. the effect being more pronounced for series 2 . However, the very similar changes for series 3 capacitors filled with the two different electrolytes suggested that the effects were related to thermal rather than chemical causes.

Further capacitors from series 3 , having the button construction and filled with sulpuric acid, were tested on shelf at $85^{\circ} \mathrm{C}$ for 4000 hours. Average capacitance increases were $6.4 \%$ and leakage currents, although increasing, remained below $0.3 \times$ $10^{-3} \mu \mathrm{A} \mu \mathrm{F}^{-1} \mathrm{~V}^{-1}$ at $20^{\circ} \mathrm{C}$. On the basis of 
TABLE X

Niobium capacitors subjected to endurance test at $85^{\circ} \mathrm{C}$ for 3000 hours

\begin{tabular}{|c|c|c|c|c|c|c|c|c|c|c|}
\hline \multirow[b]{2}{*}{ Series } & \multirow[b]{2}{*}{ Rating } & \multicolumn{3}{|c|}{$\begin{array}{l}\text { Initial values } \\
\text { at } 85^{\circ} \mathrm{C}\end{array}$} & \multicolumn{3}{|c|}{$\begin{array}{c}\text { Final values } \\
\text { at } 85^{\circ} \mathrm{C}\end{array}$} & \multicolumn{2}{|c|}{$\begin{array}{l}\text { Changes } \\
(\%)\end{array}$} & \multirow{2}{*}{$\begin{array}{l}\text { Final 1 } \\
\text { curr. at } \\
85^{\circ} \mathrm{C} \\
\left(\mu \mathrm{A} \mu \mathrm{F}^{-1}\right. \\
\left.\mathrm{V}^{-1} \times 10^{3}\right)\end{array}$} \\
\hline & & $\begin{array}{l}\text { Cap } \\
(\mu \mathrm{F})\end{array}$ & $\begin{array}{l}\tan \delta \\
(\%)\end{array}$ & $\begin{array}{l}\text { L. curr. } \\
(\mu \mathrm{A})\end{array}$ & $\begin{array}{l}\text { Cap. } \\
(\mu \mathrm{F})\end{array}$ & $\begin{array}{l}\text { Tan } \delta \\
(\%)\end{array}$ & $\begin{array}{l}\text { L. curr. } \\
(\mu \mathrm{A})\end{array}$ & Cap. & $\operatorname{Tan} \delta$ & \\
\hline $\begin{array}{l}1 \\
4\end{array}$ & $\begin{array}{l}35 \mathrm{~V} / 200 \mu \mathrm{F} \\
63 \mathrm{~V} / 60 \mu \mathrm{F}\end{array}$ & $\begin{array}{l}216 \\
62.0\end{array}$ & $\begin{array}{l}3.4 \\
1.4\end{array}$ & $\begin{array}{r}14.0 \\
3.4\end{array}$ & $\begin{array}{l}212 \\
62.7\end{array}$ & $\begin{array}{l}3.6 \\
1.7\end{array}$ & $\begin{array}{l}1.0 \\
0.4\end{array}$ & $\begin{array}{l}-1.9 \\
+1.1\end{array}$ & $\begin{array}{l}+5.9 \\
+21.5\end{array}$ & $\begin{array}{l}0.13 \\
0.10\end{array}$ \\
\hline
\end{tabular}

these tests it was concluded that sulphuric acid was a suitable working electrolyte for niobium capacitors but that rated temperatures should not normally exceed $85^{\circ} \mathrm{C}$.

Subsequent tests were all performed with tubular units using the sulphuric acid working electrolyte. The results of endurance tests performed on series 1 and 4 capacitors at $85^{\circ} \mathrm{C}$ with the rated voltage applied are given in Table $\mathrm{X}$.

A similar test carried out on series 3 capacitors for 1000 hours showed an average capacitance change of $0.1 \%$, stable dissipation factors and final leakage currents at $20^{\circ} \mathrm{C}$ of $0.05 \times 10^{-3} \mu \mathrm{A} \mu \mathrm{F}^{-1} \mathrm{~V}^{-1}$. In general all the units tested displayed acceptable parametric stability, the general performance of capacitors prepared from powder B being superior in terms of leakage current and dissipation factor. However, field crystallisation during the endurance testing was minimal for anodes prepared from both powder supplies. Some additional electrical characteristics, namely leakage current and capacitance versus temperature, and capacitance and impedance versus frequency, are given in Figure 8-11 for series

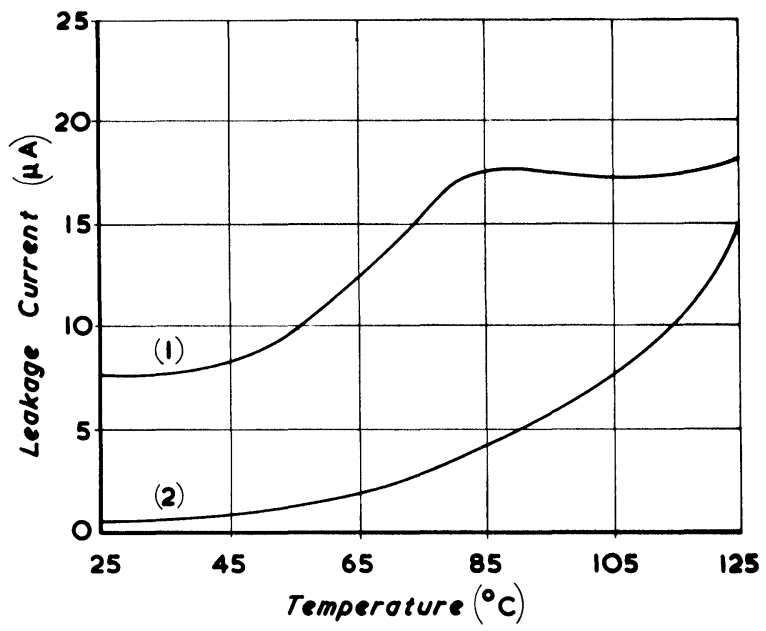

FIGURE 8 Variation of leakage current with temperature: (1) series $2(35 \mathrm{~V} / 135 \mu \mathrm{F})$, (2) series $3(35 \mathrm{~V} / 100 \mu \mathrm{F})$. Niobium capacitors.
2 and 3 capacitors. The marked decrease in capacitance with decreasing temperature and the decrease in capacitance and impedance with increasing frequency result from the distributed effect of the resistance of the electrolyte within the porous body.

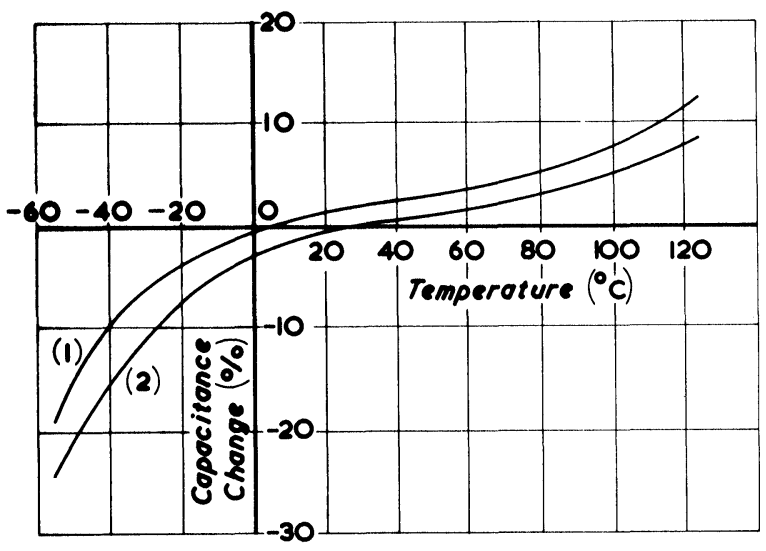

FIGURE 9 Variation of capacitance with temperature: (1) series $2(35 \mathrm{~V} / 135 \mu \mathrm{F})$, (2) series $3(35 \mathrm{~V} / 100 \mu \mathrm{F})$. Niobium capacitors.

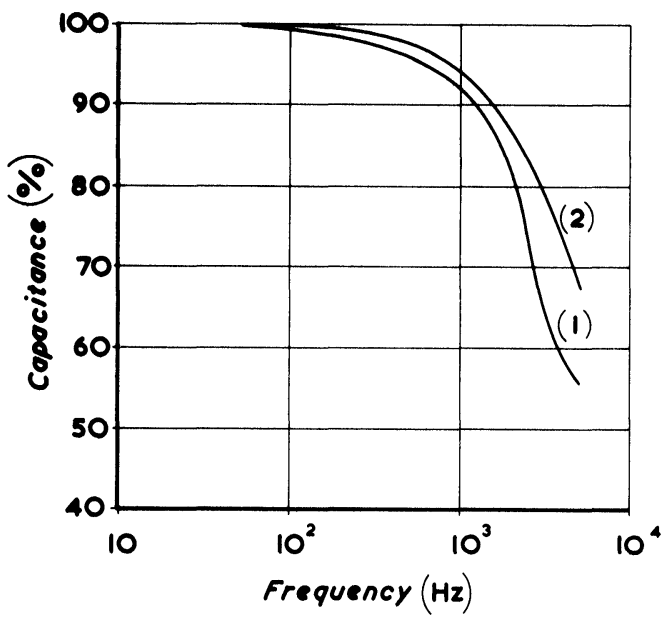

FIGURE 10 Variation of capacitance with frequency: (1) series $2(35 \mathrm{~V} / 135 \mu \mathrm{F})$, (2) series $3 \cdot(35 \mathrm{~V} / 100 \mu \mathrm{F})$. Niobium capacitors. 


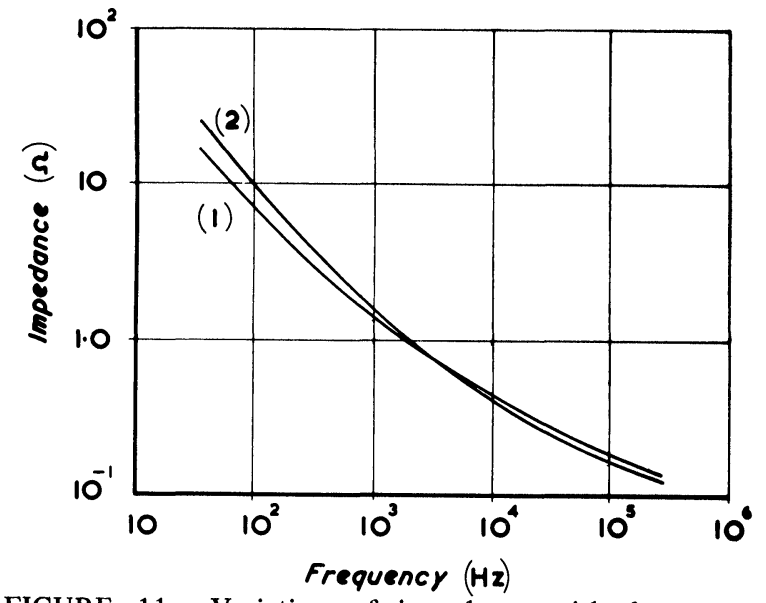

FIGURE 11 Variation of impedance with frequency: (1) series $2(35 \mathrm{~V} / 135 \mu \mathrm{F})$, (2) series $3(35 \mathrm{~V} / 100 \mu \mathrm{F})$. Niobium capacitors.

\section{DISCUSSION}

Of the two major problems encountered in preparing niobium capacitors, namely field crystallisation and heat sensitivity, it is the latter which largely controls the upper working temperature. Thus, substantial increases in capacitance and leakage current were attributed to this effect during storage on shelf at $125^{\circ} \mathrm{C}$. On the other hand, these increases in value were held to an acceptable level during a 4,000 hour period at $85^{\circ} \mathrm{C}$. The detrimental effects of field crystallisation can be greatly reduced provided suitable precautions are taken. It is important that the anodisation should be performed in a cold solution $\left(20^{\circ} \mathrm{C}\right.$ is adequate) and the electrolyte should preferably be phosphoric acid. A working electrolyte composed of concentrated sulphuric acid restrains crystalline growth and this feature can be further improved by adding a small quantity of phosphoric acid. Capacitors filled with $40 \% \mathrm{w} / \mathrm{w}$ sulphuric acid gave good results at temperatures between $-55^{\circ} \mathrm{C}$ and $85^{\circ} \mathrm{C}$ and results at $125^{\circ} \mathrm{C}$ suggested that chemical compatability with the niobium pentoxide was maintained.

The maximum surface area, corresponding to $10.000 \mu \mathrm{F} \mathrm{V} \mathrm{gm}^{-1}$, was obtained with the $8 \mu \mathrm{m}$ powder sintered at $1400^{\circ} \mathrm{C}$. The capacitance values refer to $20^{\circ} \mathrm{C}$ anodisation, and if a correction factor is applied the equivalent figure for a $90^{\circ} \mathrm{C}$ anodisation is about $8000 \mu \mathrm{F} \mathrm{V} \mathrm{gm}{ }^{-1}$. This value is close to that obtained with modern high capacitance tantalum powders (nominally $4 \mu \mathrm{m}$ particle size) using a $90^{\circ} \mathrm{C}$ anodisation temperature. However, in the present work the ratio of working voltage to forming voltage is about 0.6 of that conventionally used with tantalum and so a more realistic comparative value for niobium would be close to $5000 \mu \mathrm{F} \mathrm{V} \mathrm{gm}{ }^{-1}$. In consequence, the price of these niobium anodes is similar to that of tantalum anodes prepared from the highest capacitance powders but for the same capacitance/voltage rating the niobium bodies are twice as large. Furthermore, the reduced purity of the $8 \mu \mathrm{m}$ niobium powder limits the anodisation of sintered bodies to about $120 \mathrm{~V}$ and does not permit the preparation of capacitors capable of working much in excess of $35 \mathrm{~V}$. Anodes prepared from the $10 \mu \mathrm{m}$ powder sintered at $1800^{\circ} \mathrm{C}$ can be safely anodised to $180 \mathrm{~V}$ and operated at $63 \mathrm{~V}$. The decreased $\mu \mathrm{F}$ $\mathrm{V} \mathrm{gm}^{-1}$ value of these anodes is consistent with the larger particle size and higher sintering temperatures If powder of this purity can be obtained in a particle size approaching $4 \mu \mathrm{m}$, it should be possible to produce anodes of the same physical dimensions as the tantalum bodies, having the same capacitance/ voltage rating, costing half as much and operating at least at $35 \mathrm{~V}$. A capacitor working at $50 \mathrm{~V}$ might well be achievable.

In general, both the $35 \mathrm{~V}$ and the $63 \mathrm{~V}$ capacitors that have been subjected to endurance tests at $85^{\circ} \mathrm{C}$ for 3000 hours have shown good stability of capacitance and dissipation factor. Final leakage currents at $85^{\circ} \mathrm{C}$ were in the region of $10^{-4} \mu \mathrm{A} \mu \mathrm{F}^{-1} \mathrm{~V}^{-1}$, a value fully comparable with that of tantalum capacitors and field crystallisation was restrained to a minimum.

\section{CONCLUSIONS}

1) The radial growth rate of crystalline oxide during the anodisation of niobium can be reduced by employing a phosphoric acid electrolyte at low temperature.

2) Thermal effects limit the temperature of operation of niobium capacitors to $85^{\circ} \mathrm{C}$.

3) Capacitors rated at $35 \mathrm{~V} / 200 \mu \mathrm{F}$ and $63 \mathrm{~V} / 60 \mu \mathrm{F}$ have shown good stability on endurance tests at $85^{\circ} \mathrm{C}$.

4) Niobium powders of nominal $4 \mu \mathrm{m}$ particle size will be necessary before the anode cost can be reduced substantially below that of tantalum.

\section{ACKNOWLEDGEMENTS}

The authors would like to thank Mr. L. Smith of the Chemical and Metallurgical Division of the Plessey Company 
at Towcester for preparing the niobium anodes, assembling the capacitors and for making some of the electrical measurements. Mr. G. Donachie is thanked for help with some of the experimental work and Mr. N. S. Griffin for the scanning electron micrographs. This work is published by permission of The Plessey Company Limited.

\section{REFERENCES}

1. D. A. Vermilyea, J. Electrochem. Soc., 102207 (1955).

2. D. A. Vermilyea, J. Electrochem. Soc., 104542 (1957).

3. N. F. Jackson, J. Applied Electrochem, 391 (1973).

4. D. A. Smyth and T. B. Tripp, J. Electrochem. Soc., 113 1048 (1966). 

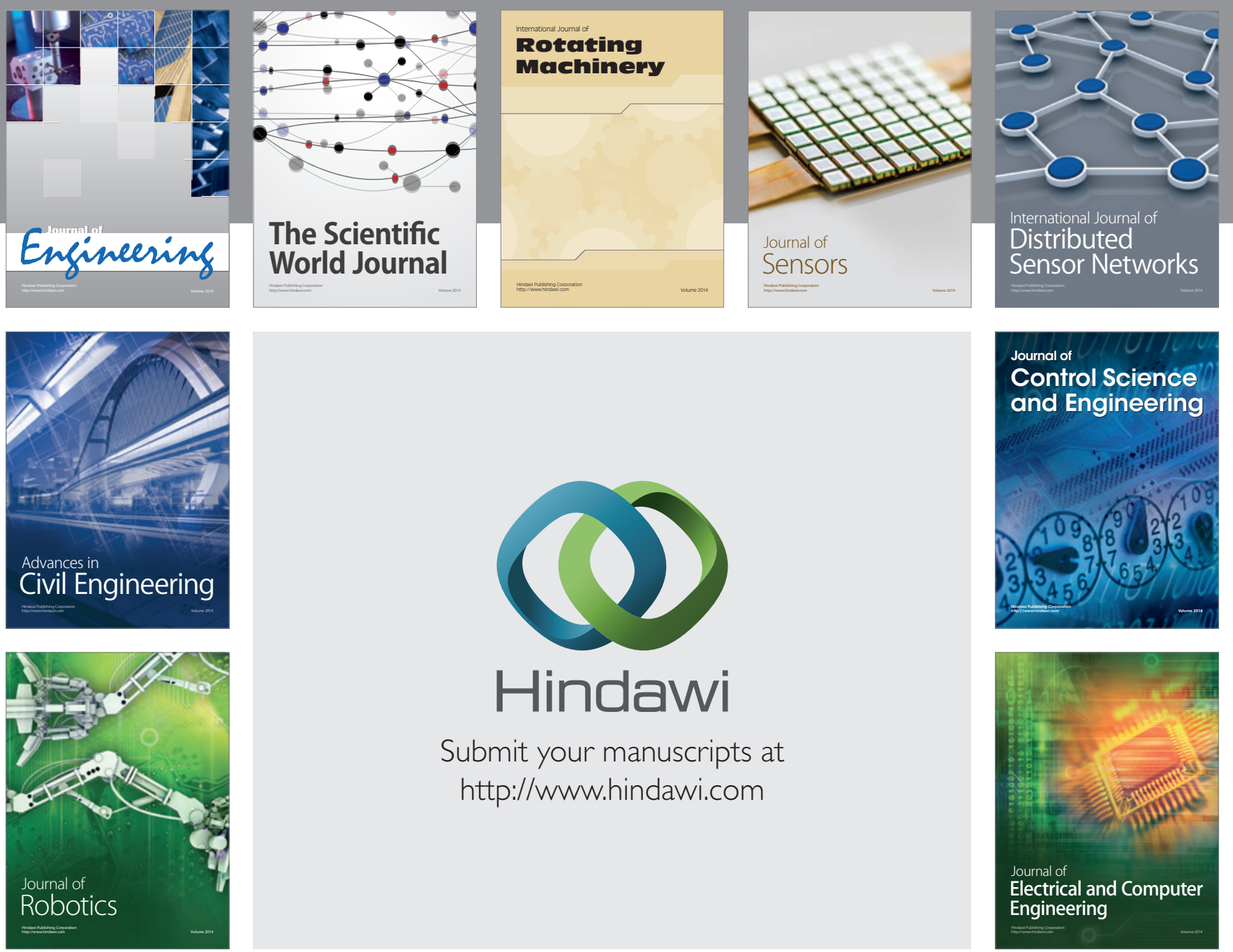

Submit your manuscripts at

http://www.hindawi.com
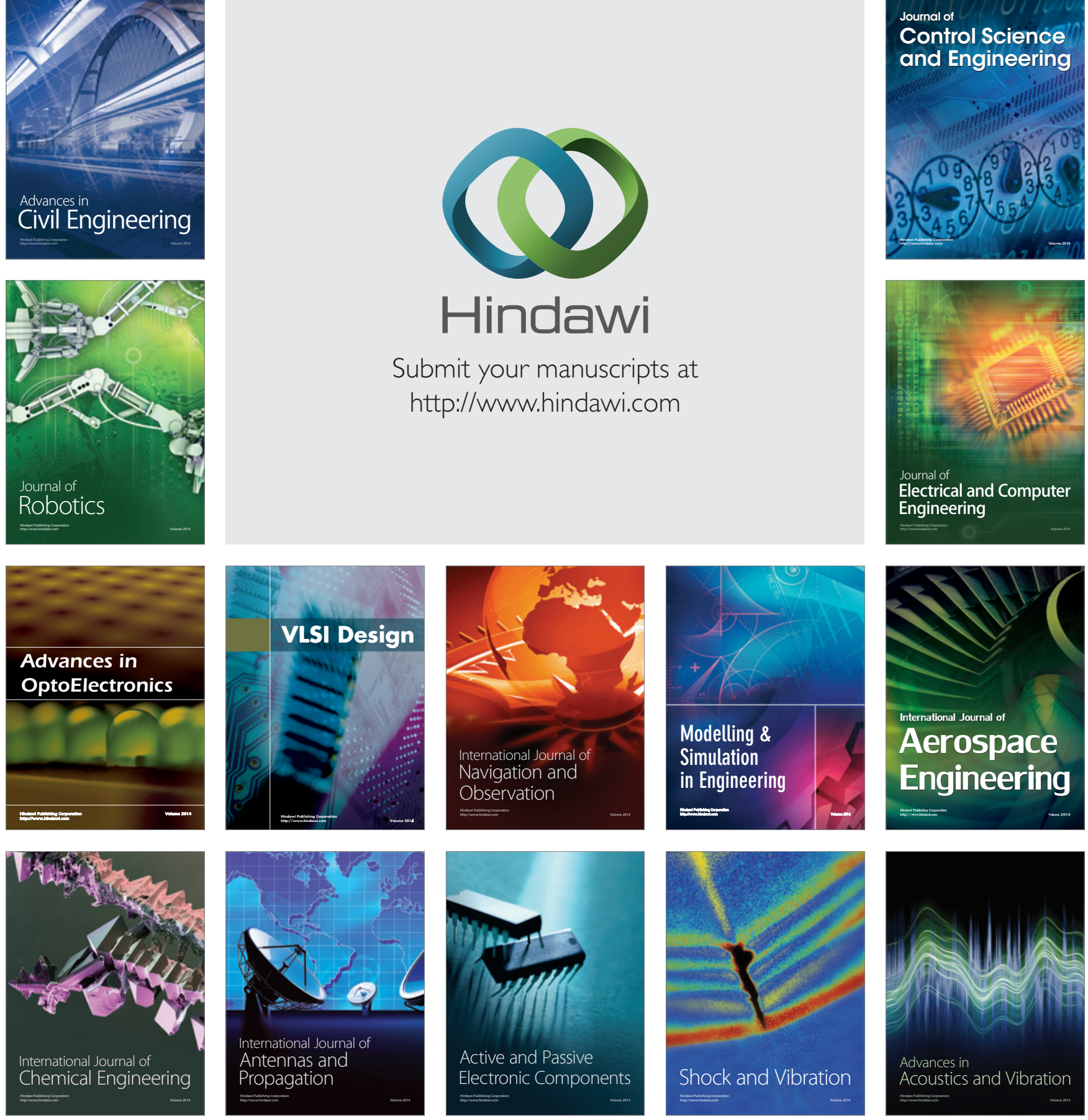